\title{
A Comparison Study on the Arsenate Adsorption Behavior of Calcium-Bearing Materials
}

\author{
Han Wang and Hong Zhu * \\ College of Materials Science and Engineering, Nanjing Tech University, Nanjing 210009, China; \\ hwang1227@163.com \\ * Correspondence: hzhu@njtech.edu.cn
}

Received: 27 May 2019; Accepted: 14 June 2019; Published: 16 June 2019

\begin{abstract}
The calcium-bearing adsorbents are widely used in the treatment of arsenic-containing wastewater due to their excellent treatment effect and economy. In order to obtain high-efficient adsorbents for arsenate $(\mathrm{As}(\mathrm{V}))$ removal, the adsorption behavior of calcium oxide $(\mathrm{CaO})$, calcium fluoride $\left(\mathrm{CaF}_{2}\right)$ and calcium carbonate $\left(\mathrm{CaCO}_{3}\right)$ on $\mathrm{As}(\mathrm{V})$ in aqueous solution at different concentrations were explored. The adsorption mechanism was also explored based on surface characteristics: morphology, specific surface area, as well as their effective calcium content. Not only that, the chemical stability of these materials was further studied. Results exhibited that the $\mathrm{As}(\mathrm{V})$ removal capability of these materials is in the following order, $\mathrm{CaO}>\mathrm{CaF}_{2}>\mathrm{CaCO}_{3}$. When $\mathrm{CaO}$ served as an absorbent, $\mathrm{As}(\mathrm{V})$ with initial concentration of $0.2 \mathrm{mg} / \mathrm{L}$ can be reduced to $0.383 \times 10^{-3} \mathrm{mg} / \mathrm{L}$ in $10 \mathrm{~min}$. Moreover, the capabilities of $\mathrm{CaO}, \mathrm{CaF}_{2}$ and $\mathrm{CaCO}_{3}$ for removing $\mathrm{As}(\mathrm{V})$ are positively correlated with their effective calcium content in aqueous solution, which provide the basis for selecting calcium-bearing materials with excellently comprehensive properties for the field of $\mathrm{As}(\mathrm{V})$ removal in aqueous solution. What's more, all three materials exhibit great chemical stability after adsorption of $\mathrm{As}(\mathrm{V})$.
\end{abstract}

Keywords: calcium-bearing materials; As(V); adsorption properties; adsorption mechanism

\section{Introduction}

With the rapid development of industry and agriculture, the problem of water pollution caused by arsenic is becoming increasingly serious [1-3]. Arsenic is a carcinogen with a wide range of biological effects [4,5]. Long-term drinking of arsenic-containing water will lead to a series of health problems such as melanosis, keratosis and cancer, etc. [6-8]. The hygienic standards of highest concentration of arsenic in drinking water are strictly defined by the World Health Organization (WHO), Japan, America and China (less than $0.01 \mathrm{mg} / \mathrm{L}$ ) [9]. Not only that, the highest concentration of arsenic in effluent industrial wastewater in China is also strictly defined (less than $0.5 \mathrm{mg} / \mathrm{L}$ ). There have been many reports about arsenic contamination in water bodies over the years [10,11]. Arsenic pollution in water is widespread in more than 70 countries, especially in Bangladesh, India and China [12,13]. Therefore, limiting the concentration of arsenic in water is extremely urgent and significant to reduce the harm of arsenic. Generally speaking, the treatment methods for arsenic pollution in water can be divided into the chemical precipitation method, ion exchange method, membrane separation method, electrochemical method, and adsorption method [14-16]. Compared with the other methods, the adsorption method is widely used because of the advantages of a wide source of raw materials, easy operation and high efficiency, etc.

Among many adsorbents, calcium-bearing adsorbents are widely used in the treatment of arsenic-containing wastewater due to their excellent treatment effect and economy, e.g., by calcite and lime $[17,18]$. The adsorption mechanism of arsenic by calcium-containing adsorbents is mainly the combination of calcium arsenate between arsenate anions and calcium ions $\left(\mathrm{Ca}^{2+}\right)$. As Bothe et al. [19] 
reported, the main reaction product was calcium arsenate using lime as an adsorbent to remove arsenic. Although there have been many studies on the treatment of arsenic-containing wastewater by calcium-bearing materials, the arsenic removal efficiency of calcium-bearing materials with different types and particle sizes is significantly different. Furthermore, there also a lack of systematical comparison reports on their arsenic-removal performance. More than that, the kinetic process and mechanism of arsenic removal on different calcium-bearing materials are rarely discussed.

In order to obtain high-efficient calcium-bearing adsorbents for arsenate $(\mathrm{As}(\mathrm{V}))$ removal and compare their $\mathrm{As}(\mathrm{V})$ removal mechanisms, the $\mathrm{As}(\mathrm{V})$ adsorption behaviors in water solution of $\mathrm{CaO}$, $\mathrm{CaF}_{2}$ and $\mathrm{CaCO}_{3}$ were studied. Not only were the capabilities of removing $\mathrm{As}(\mathrm{V})$ for these materials compared according to removal rates and adsorption rates, but also $\mathrm{As}(\mathrm{V})$ removal mechanisms were analyzed based on calculation of the material's crystal structures and specific surface areas. The study will provide the basis for selecting calcium-bearing materials with excellently comprehensive properties for the field of arsenic removal in aqueous solution.

\section{Materials and Methods}

\subsection{Materials}

Calcium fluoride $\left(\mathrm{CaF}_{2}\right)$ and calcium carbonate $\left(\mathrm{CaCO}_{3}\right)$ were purchased from Sinopharm Chemical Reagent Co., Ltd. and Beijing Huaweiruike Chemical Co., Ltd., respectively.

Calcium oxide $\left(\mathrm{CaO}\right.$, with a certain thickness on the surface of $\left.\mathrm{CaCO}_{3}\right)$ was obtained by calcining and decomposing calcium carbonate $\left(\mathrm{CaCO}_{3}\right)$, and $\mathrm{CaCO}_{3}$ was used to prepare $\mathrm{CaO}$ samples is the same substance as $\mathrm{CaCO}_{3}$ used in this study.

\subsection{Experimental Methods}

\subsubsection{Preparation of Arsenic-Containing Aqueous Solution}

$\mathrm{Na}_{3} \mathrm{AsO}_{4} \cdot 12 \mathrm{H}_{2} \mathrm{O}$ (analytical grade, $5.6576 \mathrm{~g}$ ) was dissolved into deionized water using a volumetric flask of $1000 \mathrm{~mL}$. A simulated stock solution of $1000 \mathrm{mg} / \mathrm{L} \mathrm{As}(\mathrm{V})$ was prepared. The as-prepared arsenic stock solution was diluted to the required concentrations $(0.2$ and $30 \mathrm{mg} / \mathrm{L})$ with deionized water, and the $\mathrm{pH}$ value was adjusted to $7.0 \pm 0.1$ by hydrochloric acid $(\mathrm{HCl}$, analytical grade) and Sodium hydroxide ( $\mathrm{NaOH}$, analytical grade) using $\mathrm{pH}$ meter (PHS-25, Shanghai Yidian Scientific Instrument co., Ltd., Shanghai, China).

\subsubsection{Adsorption Experiment}

Each adsorbent $(0.2 \mathrm{~g})$ was separately added to glass containers prefilled with $20 \mathrm{~mL}$ arsenic-containing aqueous solution. The obtained suspensions were mixed in a water bath thermostatic oscillator for a certain period of time at a $\mathrm{pH}$ of 7 and temperature of $25^{\circ} \mathrm{C}$. Then, supernatants were filtered through a membrane of $0.22 \mu \mathrm{m}$, and $\mathrm{As}(\mathrm{V})$ concentrations were detected by AFS-230E double-channel hydride generation atomic fluorescence photometer.

The adsorption quantity of the adsorbents was calculated according to the Equation (1):

$$
q_{e}=\left(C_{0}-C_{e}\right) V / m
$$

where $q_{e}$ is the adsorption quantity at adsorption equilibrium, $\mathrm{mg} / \mathrm{g} ; V$ is the volume of arsenic-containing solution, $\mathrm{L} ; m$ is the adsorbent dosage, $\mathrm{g} ; C_{0}$ and $C_{e}$ are the initial and equilibrium concentrations of arsenic in the solution, respectively, $\mathrm{mg} / \mathrm{L}$.

\subsection{Characterizations of Calcium-Bearing Materials}

The decomposition temperature of $\mathrm{CaCO}_{3}$ was analyzed by thermogravimetric analysis (TGA, METTLERTGA2, Mettler Toledo, Zurich, Switzerland). The morphologies and particle sizes of 
the adsorbents were observed by scanning electronic microscope (SEM, JSM-6510, Tokyo, Japan). The specific surface areas of the adsorbents were detected by Brunauer-Emmett-Teller (BET, ASAP2460, Micromeritics, Atlanta, Georgia, America). The crystal structures of materials were identified by X-ray diffraction (XRD, Smartlab (3 kw), Rigaku Corporation, Tokyo, Japan), testing conditions: room temperature, voltage of $40 \mathrm{kV}$ and current of $30 \mathrm{~mA}, \mathrm{Cu} \mathrm{K}$ alpha, two-theta testing angle range: 5-80 , testing speed: $5 \% \mathrm{~min}$.

\section{Results and Discussion}

\subsection{Characteristics of $\mathrm{CaO}$}

The $\mathrm{CaO}$ used in this study was obtained by decomposition of $\mathrm{CaCO}_{3}$ at high temperature. Therefore, the initial decomposition temperature of $\mathrm{CaCO}_{3}$ need to be explored, and the TGA of $\mathrm{CaCO}_{3}$ was carried out under air atmosphere with a heating rate of $5^{\circ} \mathrm{C} / \mathrm{min}$. Figure 1 a shows that the initial decomposition temperature of $\mathrm{CaCO}_{3}$ was about $573{ }^{\circ} \mathrm{C}$, the weightlessness rate of $\mathrm{CaCO}_{3}$ was $13 \%$ at $633^{\circ} \mathrm{C}$, and completely weightless at $693{ }^{\circ} \mathrm{C}$. In order to prepare $\mathrm{CaO}$ for the experiment, $\mathrm{CaCO}_{3}$ was put into a muffle furnace for burning at $633^{\circ} \mathrm{C}$, and the other burning conditions were the same as testing of TGA. In addition, $\mathrm{CaO}$ mass fraction was $15.9 \%$ in the obtained product. As shown in Figure $1 \mathrm{~b}$, the $\mathrm{CaCO}_{3}$ used in this study was a calcite crystal. The peaks of $\mathrm{CaCO}_{3}$ at $23.1^{\circ}, 29.4^{\circ}, 36.0^{\circ}$ and $39.4^{\circ}$ are corresponding to the crystal face of $(1,0,2),(410),(01,1)$ and $(1,1-3)$, respectively. Combining Figure $1 \mathrm{~b}$ and $\mathrm{c}$, the peaks at $39^{\circ}$ and $43^{\circ}$ of prepared $\mathrm{CaO}$ had a slight shift compared with pure $\mathrm{CaCO}_{3}$, which indicate that the samples cauterized at $633^{\circ} \mathrm{C}$ had two phases of $\mathrm{CaCO}_{3}$ and $\mathrm{CaO}$, thus proving that $\mathrm{CaO}$ was synthesized on the surface of $\mathrm{CaCO}_{3}$ with a certain thickness.
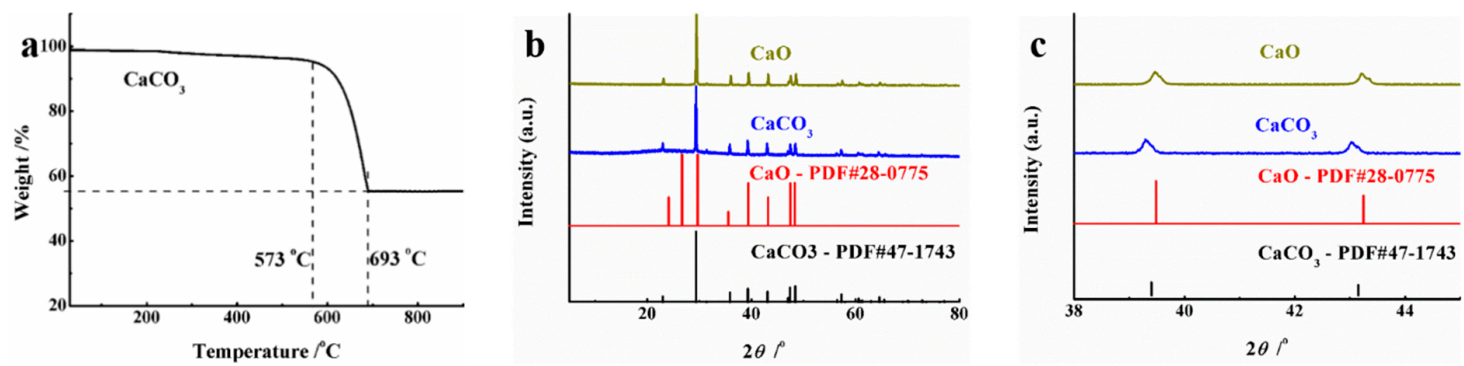

Figure 1. (a) Thermogravimetric analysis (TGA) curve of $\mathrm{CaCO}_{3}$, (b) and (c) X-ray diffraction (XRD) patterns of $\mathrm{CaO}$ and $\mathrm{CaCO}_{3}$ at different two-theta testing angle ranges of $5-80^{\circ}$ and $38-45^{\circ}$.

\subsection{The As(V) Removal Capacities of Three Calcium-Bearing Materials at Different Initial Concentrations}

The $\mathrm{As}(\mathrm{V})$ removal rates with different $\mathrm{As}(\mathrm{V})$ initial concentrations of three calcium-bearing materials after $24 \mathrm{~h}$ are shown in Figure 2. It can be found that there were significant differences in the $\mathrm{As}(\mathrm{V})$ removal capacities of the three calcium-bearing materials. Especially, CaO exhibited the strongest removal ability, followed by $\mathrm{CaF}_{2}$ and $\mathrm{CaCO}_{3}$. The removal rates of $\mathrm{As}(\mathrm{V})$ with initial concentration of $0.2 \mathrm{mg} / \mathrm{L}$ for $\mathrm{CaO}, \mathrm{CaF}_{2}$ and $\mathrm{CaCO}_{3}$ were $99.9 \%, 68.0 \%$ and $36.1 \%$, respectively. When the initial concentration of $\mathrm{As}(\mathrm{V})$ was increased to $30 \mathrm{mg} / \mathrm{L}$, the removal rates of $\mathrm{As}(\mathrm{V})$ for the three calcium-bearing materials were all significantly reduced, which were $62.6 \%, 36.4 \%$ and $20.3 \%$, respectively. Compared with initial concentration of $0.2 \mathrm{mg} / \mathrm{L}$, the reduction rates of adsorption capacities for the $\mathrm{CaO}, \mathrm{CaF}_{2}$ and $\mathrm{CaCO}_{3}$ were $37.3 \%, 46.5 \%$ and $43.8 \%$, respectively, under initial concentration of $30 \mathrm{mg} / \mathrm{L}$. Among them, $\mathrm{CaO}$ with the best adsorption performance decreased the least. 


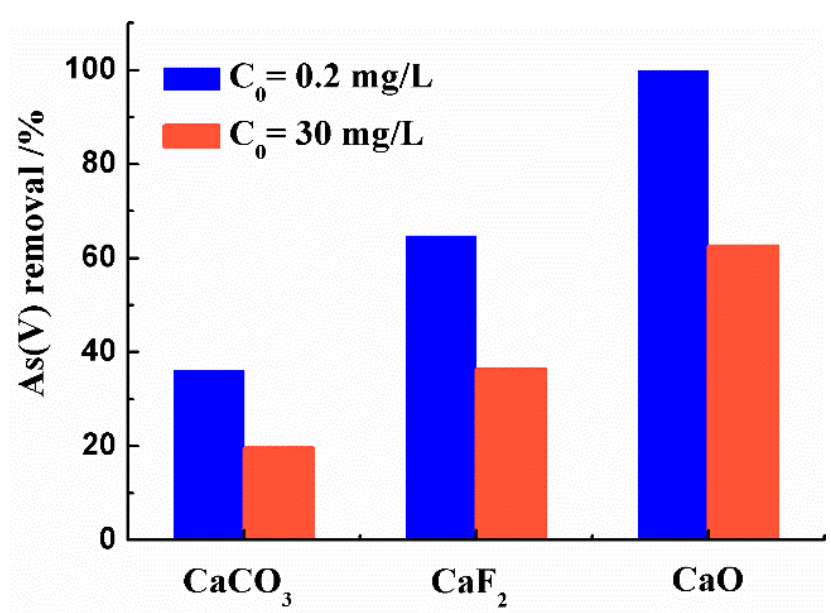

Figure 2. Arsenate $(\mathrm{As}(\mathrm{V}))$ adsorption capacities of three calcium-bearing materials at the $\mathrm{As}(\mathrm{V})$ initial concentration of $0.2 \mathrm{mg} / \mathrm{L}$ and $30 \mathrm{mg} / \mathrm{L}$. (The dosage of calcium-containing materials was 10 $\mathrm{g} / \mathrm{L}$, the adsorption time was $24 \mathrm{~h}$, the $\mathrm{pH}$ value of aqueous solution was 7 , and the reaction temperature was $25^{\circ} \mathrm{C}$.)

\subsection{Effects of Adsorption Time on the As(V) Removal Capacities of Three Calcium-Bearing Materials}

The removal rates of $\mathrm{As}(\mathrm{V})$ with initial concentration of $0.2 \mathrm{mg} / \mathrm{L}$ for the three calcium-bearing materials at different adsorption times are shown in Figure $3 \mathrm{a}$. It can be found that, $\mathrm{CaO}, \mathrm{CaF}_{2}$, and $\mathrm{CaCO}_{3}$ can reach the adsorption equilibrium at $10 \mathrm{~min}$, and the removal rates of $\mathrm{As}(\mathrm{V})$ were $99.8 \%$, $69.1 \%$ and $31.8 \%$, respectively.
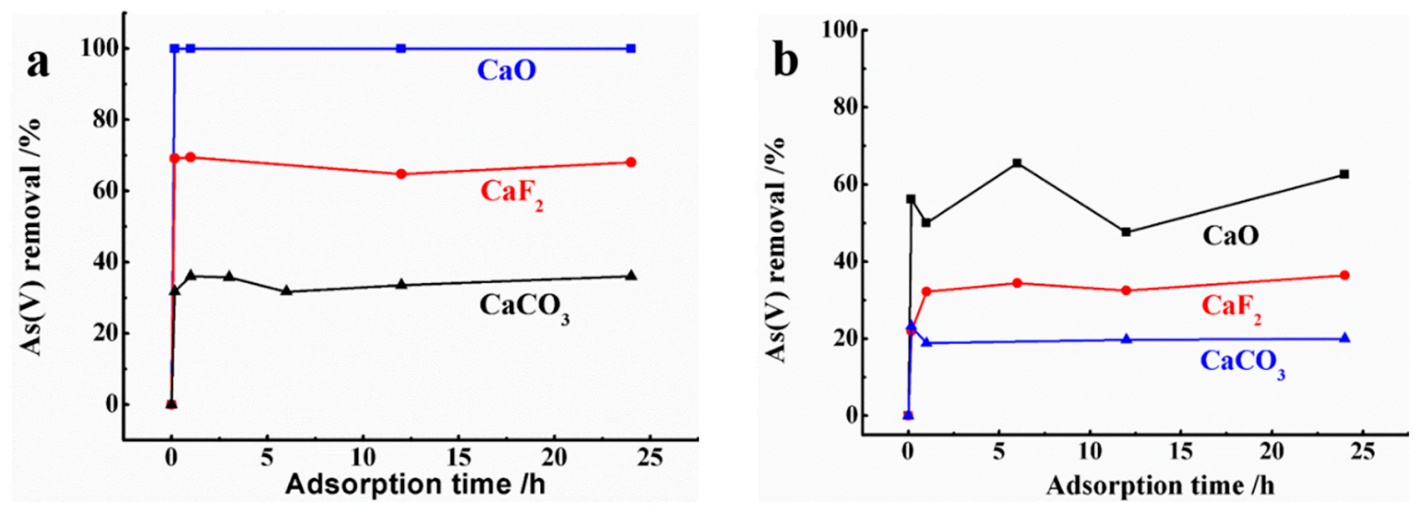

Figure 3. $\mathrm{As}(\mathrm{V})$ adsorption capacities of three calcium-bearing materials as function of adsorption time at (a) $0.2 \mathrm{mg} / \mathrm{L}$ and (b) $30 \mathrm{mg} / \mathrm{L}$. (The dosage of calcium-containing materials was $10 \mathrm{~g} / \mathrm{L}$, the $\mathrm{pH}$ value of aqueous solution was 7 , and the reaction temperature was $25^{\circ} \mathrm{C}$.)

The removal rates of $\mathrm{As}(\mathrm{V})$ with initial concentration of $30 \mathrm{mg} / \mathrm{L}$ for the three calcium-bearing materials at different adsorption times are shown in Figure 3b. By comparing the effects of adsorption time on the $\mathrm{As}(\mathrm{V})$ removal capacities at low (Figure $3 \mathrm{a}$ ) and high (Figure $3 \mathrm{~b}$ ) initial concentrations, it can be concluded that increasing the initial concentration has a different influence on the time to reach the adsorption equilibrium for the three calcium-bearing materials. As for $\mathrm{CaO}$, the time of reaching adsorption equilibrium has no significant change. As shown in Figure $3 b$, when $\mathrm{CaO}$ was adsorbed for $10 \mathrm{~min}$, the removal rate of $\mathrm{As}(\mathrm{V})$ reached $56.2 \%$. The free calcium content of $\mathrm{CaO}$ in aqueous solution is as high as $42.00 \times 10^{-2} \mathrm{mmol}$, which mainly forms calcium arsenate precipitation to remove $\mathrm{As}(\mathrm{V})$. But the formed calcium arsenate precipitate is unstable [20], resulting in a wide fluctuation range of $\mathrm{As}(\mathrm{V})$ removal rate with the prolonging of adsorption time. The time for $\mathrm{CaF}_{2}$ to reach adsorption equilibrium was slightly extended. When the adsorption time increased from $10 \mathrm{~min}$ to $60 \mathrm{~min}$, the removal rate of $\mathrm{As}(\mathrm{V})$ increased slowly from $21.9 \%$ to $32.2 \%$, and the $\mathrm{CaF}_{2}$ reached 
adsorption equilibrium. The time for $\mathrm{CaCO}_{3}$ to reach adsorption equilibrium has no significant change. When $\mathrm{CaCO}_{3}$ was adsorbed for $10 \mathrm{~min}$, the removal rate of $\mathrm{As}(\mathrm{V})$ reached $23.2 \%$.

In general, when the initial concentration of $\mathrm{As}(\mathrm{V})$ increased from $0.2 \mathrm{mg} / \mathrm{L}$ to $30 \mathrm{mg} / \mathrm{L}$, both $\mathrm{CaO}$ and $\mathrm{CaCO}_{3}$ can reach adsorption equilibrium in $10 \mathrm{~min}$, and the prolonged time has little effect on the removal rate of $\mathrm{As}(\mathrm{V})$. Compared with $\mathrm{CaO}$ and $\mathrm{CaCO}_{3}$, the time for $\mathrm{CaF}_{2}$ to reach adsorption equilibrium is slightly prolonged. What's more, using $\mathrm{CaO}$ as an adsorbent to treat $\mathrm{As}(\mathrm{V})$ at the concentration of $0.2 \mathrm{mg} / \mathrm{L}$ in aqueous solution can meet the requirement of arsenic limit $(0.01 \mathrm{mg} / \mathrm{L})$ of the China sanitary standard for drinking water, while $\mathrm{CaF}_{2}$ used as an adsorbent to treat $\mathrm{As}(\mathrm{V})$ of $0.2 \mathrm{mg} / \mathrm{L}$ in aqueous solution can meet the requirement of arsenic limit $(0.1 \mathrm{mg} / \mathrm{L})$ of China water quality standard for farmland irrigation (category II).

\subsection{Mechanism Analysis}

The particle size, morphology and specific surface area are very important surface characteristics for adsorbents. Moreover, the main mechanism for the removal of $\mathrm{As}(\mathrm{V})$ by calcium-bearing materials is the formation of insoluble calcium arsenate salt generated by arsenate anions and calcium ions [21]. In order to demonstrate the mechanism of $\mathrm{As}(\mathrm{V})$ removal by calcium-bearing materials, the particle morphologies, specific surface areas and effective calcium content in aqueous solution of the three materials were compared. Especially, the effective calcium content of these materials is the sum of the surface calcium content and the free calcium content in the aqueous solution.

\subsubsection{Analysis of Particle Morphologies and Specific Surface Areas}

SEM images of the three calcium-bearing materials before adsorption of $\mathrm{As}(\mathrm{V})$ are shown in Figure 4. Figure 4a and cexhibit $\mathrm{CaCO}_{3}$ and $\mathrm{CaO}$, respectively. Both $\mathrm{CaCO}_{3}$ and $\mathrm{CaO}$ are spherical particles, and their particle sizes have no significatly change before and after burning, remaining within the range of $0.5 \sim 1 \mu \mathrm{m}$. Figure $4 \mathrm{~b}$ shows that $\mathrm{CaF}_{2}$ has fine particle smaller than $50 \mathrm{~nm}$.
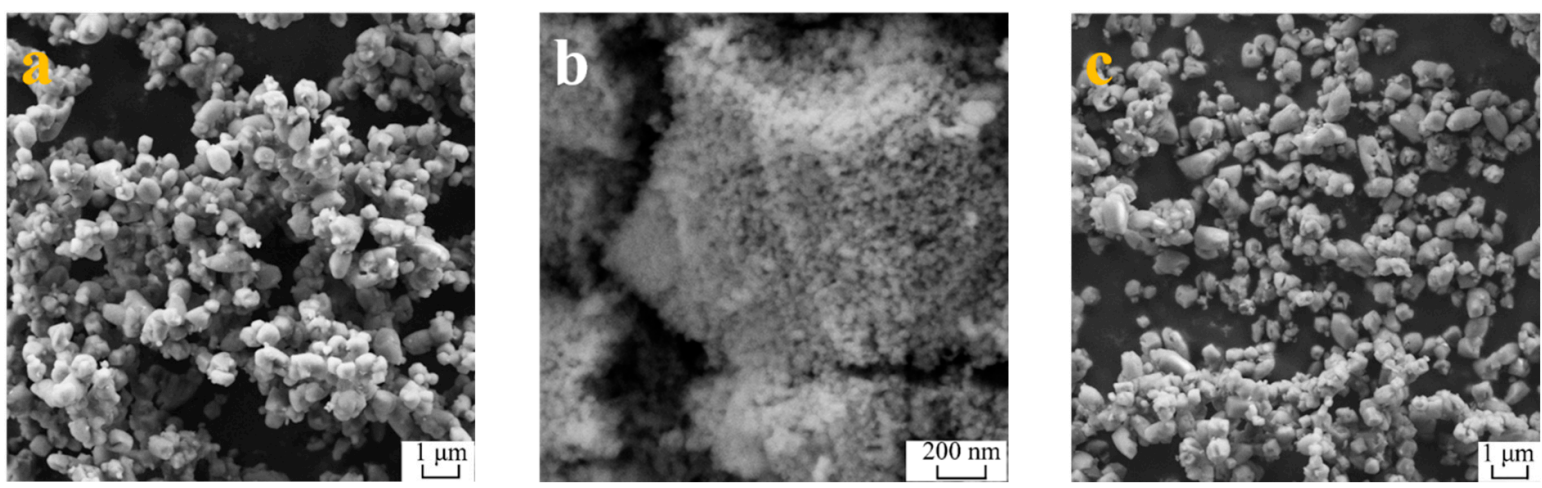

Figure 4. SEM images of (a) $\mathrm{CaO},(\mathbf{b}) \mathrm{CaF}_{2}$ and (c) $\mathrm{CaCO}_{3}$.

The nitrogen adsorption-desorption isotherms of the three calcium-containing materials are shown in Figure 5, from which we can get that the specific surface areas of these materials, is in the following order, $\mathrm{CaF}_{2}\left(21.05 \mathrm{~m}^{2} / \mathrm{g}\right)>\mathrm{CaCO}_{3}\left(4.62 \mathrm{~m}^{2} / \mathrm{g}\right)>\mathrm{CaO}\left(3.32 \mathrm{~m}^{2} / \mathrm{g}\right)$.

$\mathrm{As}(\mathrm{V})$ adsorption capacity of the three calcium-bearing materials at the initial concentration of $30 \mathrm{mg} / \mathrm{L}$ is in the following order, $\mathrm{CaO}(2.00 \mathrm{mg} / \mathrm{g})>\mathrm{CaF}_{2}(1.10 \mathrm{mg} / \mathrm{g})>\mathrm{CaCO}_{3}(0.63 \mathrm{mg} / \mathrm{g})$. Taking both morphological observation and specific surface areas into consideration, $\mathrm{CaF}_{2}$ with smallest particle size and the largest specific surface area did not show the best adsorption capacity on $\mathrm{As}(\mathrm{V})$; The specific surface areas of $\mathrm{CaO}$ and $\mathrm{CaCO}_{3}$ were similar, but the adsorption capacity of $\mathrm{As}(\mathrm{V})$ was significantly different. Therefore, we can draw a preliminary conclusion that the morphology and specific surface area were not the significant determinants for the $\mathrm{As}(\mathrm{V})$ removal abilities of the three calcium-bearing materials. 


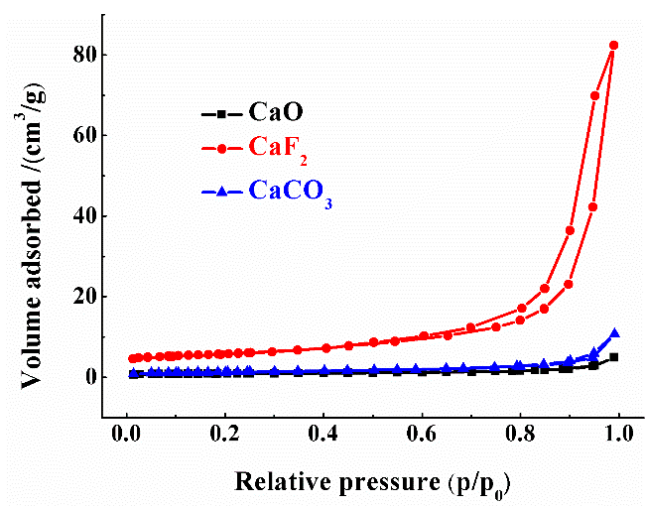

Figure 5. $\mathrm{N}_{2}$ adsorption and desorption isotherms of three calcium-bearing materials.

\subsubsection{Analysis of Effective Calcium Content}

Considering the crystal structure parameters [22-24], specific surface areas and solubility in water of the three calcium-bearing materials, the effective calcium content in aqueous solution was calculated respectively. The calculation results are shown in Table 1 . The calculation method is as follows:

$m_{0}$ is calculated according to the solubility of each substance.

$$
\begin{gathered}
s_{1}=s_{0} \times m_{0} \\
N=\frac{1}{s_{2}} \\
n_{1}=n_{0} \times N \\
n_{2}=n_{1} \times s_{1}
\end{gathered}
$$

$n_{3}$ is calculated based on solubility of each substance.

$$
n_{4}=n_{2}+n_{3}
$$

where $m_{0}$ is the mass of solid phase in solution, $\mathrm{g}$; $s_{0}$ is the specific surface area of substance, $\mathrm{m}^{2} / \mathrm{g} ; \mathrm{s}_{1}$ is the surface area of solid substance in solution, $\mathrm{m}^{2} ; \mathrm{s}_{2}$ is the cross-sectional area of a crystal cell, $\mathrm{m}^{2} ; N$ is the number of crystal cells per unit area; $n_{0}$ and $n_{1}$ are the calcium content of per crystal cell and per unit area of substance, respectively, $\mathrm{mmol} ; n_{2}$ is the surface calcium content of solid phase in solution, mmol; $n_{3}$ is the free calcium content in solution, mmol; $n_{4}$ is the effective calcium content in solution, mmol.

Table 1. Effective calcium content of the three calcium-bearing materials.

\begin{tabular}{cccccc}
\hline Material Names & $\boldsymbol{m}_{\mathbf{0}} \mathbf{( g )}$ & $\boldsymbol{n}_{\mathbf{1}} \mathbf{( \mathbf { 1 0 } ^ { - \mathbf { 2 } } \mathbf { ~ } \mathbf { m o l } )}$ & $\boldsymbol{n}_{\mathbf{2}} \mathbf{( \mathbf { 1 0 } ^ { - \mathbf { 2 } } \mathbf { ~ } \mathbf { m o l } )}$ & $\boldsymbol{n}_{\mathbf{3}} \mathbf{( \mathbf { 1 0 } ^ { - \mathbf { 2 } } \mathbf { ~ } \mathbf { m o l } )}$ & $\left.\boldsymbol{n}_{\mathbf{4}} \mathbf{( 1 0}^{\mathbf{2}} \mathbf{~} \mathbf{m m o l}\right)$ \\
\hline $\mathrm{CaO}$ & 0.17 & 2.89 & 1.69 & 42.00 & 43.70 \\
$\mathrm{CaF}_{2}$ & 0.20 & 2.24 & 9.43 & 0.38 & 9.81 \\
$\mathrm{CaCO}_{3}$ & 0.20 & 3.14 & 2.90 & 0.13 & 3.03 \\
\hline
\end{tabular}

Note: The above calculation results are based on the aqueous solution volume of $20 \mathrm{~mL}$.

As can be seen from Table 1 , the effective calcium content of $\mathrm{CaO}, \mathrm{CaF}_{2}$ and $\mathrm{CaCO}_{3}$ in aqueous solution of $20 \mathrm{~mL}$ is in flowing descending order: $43.70 \times 10^{-2}, 9.81 \times 10^{-2}, 3.03 \times 10^{-2} \mathrm{mmol}$. The $\mathrm{As}(\mathrm{V})$ adsorption quantity of $\mathrm{CaO}, \mathrm{CaF}_{2}$ and $\mathrm{CaCO}_{3}$ are $2.00,1.10$ and $0.63 \mathrm{mg} / \mathrm{g}$, corresponding to their effective calcium content in aqueous solution, indicating that the $\mathrm{As}(\mathrm{V})$ removal capacity of calcium-bearing materials is related to the effective calcium content in aqueous solution. However, the absolute value of the effective calcium content and adsorption quantity of $\mathrm{CaO}, \mathrm{CaF}_{2}$ and $\mathrm{CaCO}_{3}$ in aqueous solution did not increase by a certain proportion, indicating that the types of anions in calcium materials would affect the chemical binding abilities of calcium ions and arsenate anions. 
The main $\mathrm{As}(\mathrm{V})$ adsorption mechanism of $\mathrm{CaO}, \mathrm{CaF}_{2}$ and $\mathrm{CaCO}_{3}$ was chemical adsorption. On the one hand, arsenate anions bind to $\mathrm{Ca}^{2+}$ on the surface of the calcium-bearing materials; On the other hand, arsenate anions directly combine with free $\mathrm{Ca}^{2+}$ in solution to form arsenate precipitates. Thus, for calcium-bearing materials with simple components, choosing materials with high effective calcium content is more beneficial to the removal of $\mathrm{As}(\mathrm{V})$.

\subsection{Chemical Stability of Three Calcium-Bearing Materials before and after Adsorption of $A s(V)$}

The chemical stability of adsorbents mainly depends on whether it's crystal form changed or not. Therefore, crystal forms of $\mathrm{CaO}, \mathrm{CaF}_{2}$ and $\mathrm{CaCO}_{3}$ were characterized by XRD before and after the adsorption of $\mathrm{As}(\mathrm{V})$, and the results are shown in Figure 6. From Figure 6 we can see that no excess emerged in the peaks, comparing pre- and post-adsorption of $\mathrm{As}(\mathrm{V})$, indicating all the three calcium-bearing materials exhibited good chemical stability under laboratory operating conditions.
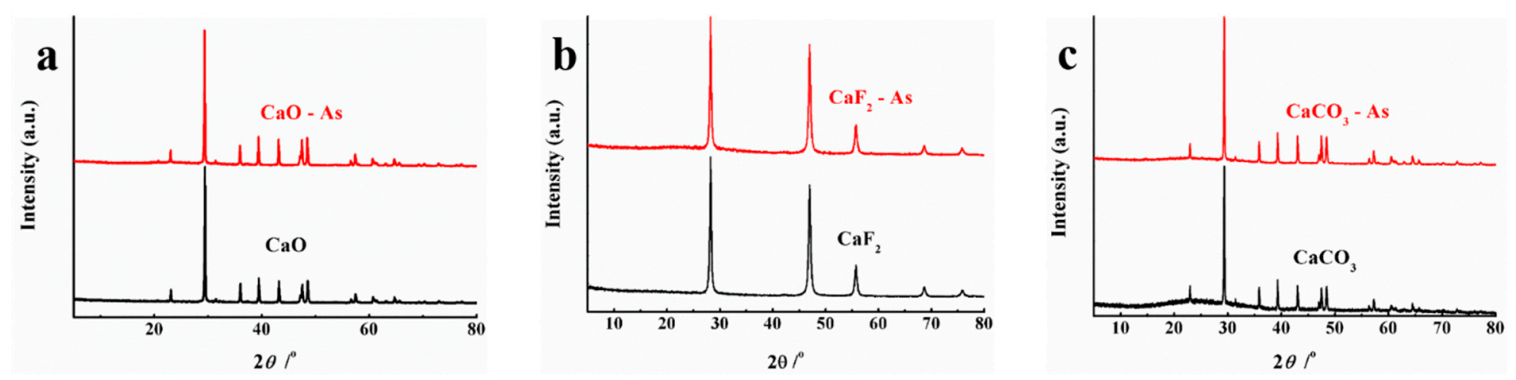

Figure 6. The $\mathrm{XRD}$ patterns of (a) $\mathrm{CaO},(\mathbf{b}) \mathrm{CaF}_{2}$ and (c) $\mathrm{CaCO}_{3}$ before and after adsorption of $\mathrm{As}(\mathrm{V})$.

\section{Conclusions}

In conclusion, not only were the capabilities of removing $\mathrm{As}(\mathrm{V})$ by $\mathrm{CaCO}_{3}, \mathrm{CaF}_{2}$ and $\mathrm{CaO}$ compared according to removal rates and adsorption rates, but also $\mathrm{As}(\mathrm{V})$ removal mechanisms of the three absorbents were analyzed based on calculation of the materials's crystal structures and specific surface areas. The results exhibit that (1) $\mathrm{CaO}$ has the best removal capacity on $\mathrm{As}(\mathrm{V})$, followed by $\mathrm{CaF}_{2}$ and $\mathrm{CaCO}_{3}$; (2) For $\mathrm{As}(\mathrm{V})$ aqueous solution with initial concentration of $0.2 \mathrm{mg} / \mathrm{L}, \mathrm{CaO}$ and $\mathrm{CaCO}_{3}$ can reach to the adsorption equilibrium in $10 \mathrm{~min}$, while $\mathrm{CaF}_{2}$ takes $60 \mathrm{~min}$ to reach the adsorption equilibrium. Especially, $\mathrm{CaO}$ can meet the requirement of arsenic limit $(0.01 \mathrm{mg} / \mathrm{L})$ in China's drinking water sanitation standards, and it is expected to be an efficient adsorbent for the drinking water treatment with arsenic; (3) The ability of removing $\mathrm{As}(\mathrm{V})$ by $\mathrm{CaO}, \mathrm{CaF}_{2}$, and $\mathrm{CaCO}_{3}$ is mainly related to the effective calcium content in aqueous solution; (4) $\mathrm{CaO}, \mathrm{CaF}_{2}$, and $\mathrm{CaCO}_{3}$ exhibit great chemical stability after adsorption of $\mathrm{As}(\mathrm{V})$. The study will provide the basis for selecting high-effective calcium-bearing materials for the field of arsenic removal in aqueous solutions.

Author Contributions: Conceptualization, H.W. and H.Z.; methodology, H.Z.; software, H.W.; validation, H.W. and H.Z.; formal analysis, H.W.; investigation, H.W.; resources, H.Z.; data curation, H.Z.; writing-original draft preparation, H.W.; writing-review and editing, H.W.; visualization, H.W.; supervision, H.Z.; project administration, H.Z.; funding acquisition, H.Z.

Funding: This research received no external funding.

Conflicts of Interest: The authors declare no conflicts of interest.

\section{References}

1. Saxena, A.; Kumar, S.; Gole, P. Source mineral for the release of arsenic in the groundwater of Karanda Block, Ghazipur District, Uttar Pradesh. J. Geol. Soc. India 2014, 84, 590-596. [CrossRef]

2. Tareq, M. Source and characteristic of fluorescence humic substances in arsenic polluted groundwater of Bangladesh. J. Chin. Chem. Soc.-Taip. 2014, 61, 770-773. [CrossRef]

3. Wai, K.M.; Wu, S.L.; Li, X.L.; Jaffe, D.A.; Perry, K.D. Global atmospheric transport and source-receptor relationships for arsenic. Environ. Sci. Technol. 2016, 50, 3714-3720. [CrossRef] [PubMed] 
4. Huang, Y.T.; Wang, M.; Mao, X.F.; Qian, Y.Z.; Chen, T.J.; Zhang, Y. Concentrations of inorganic arsenic in milled rice from China and associated dietary exposure assessment. J. Agric. Food Chem. 2015, 63, 10838-10845. [CrossRef] [PubMed]

5. Cai, J.; Zhao, Y.; Liu, P.C.; Xia, B.; Zhu, Q.Y.; Wang, X.; Song, Q.; Kan, H.D.; Zhang, Y.H. Exposure to particulate air pollution during early pregnancy is associated with placental DNA methylation. Sci. Total Environ. 2017, 607, 1103-1108. [CrossRef] [PubMed]

6. Rusyniak, D.E.; Furbee, R.B.; Kirk, M.A. Thallium and arsenic poisoning in a small Midwestern town. Ann. Emerg. Med. 2002, 39, 307-311. [CrossRef] [PubMed]

7. Wu, H.J.E.; Abdel-Gawad, N.M.; Gharbaoui, Y.; Teixeira, A.L.; Pigott, T.A. An unusual case of acute psychosis with obsessive-compulsive features following arsenic poisoning. J. Psychiatr. Pract. 2017, 23, 382-385. [CrossRef] [PubMed]

8. Lu, P.H.; Tseng, J.C.; Chen, C.K.; Chen, C.H. Survival without peripheral neuropathy after massive acute arsenic poisoning: Treated by 2, 3-dimercaptopropane-1-sulphonate. J. Clin. Pharm. Ther. 2017, 42, 506-508. [CrossRef]

9. Smith, A.H.; Lingas, E.O.; Rahman, M. Contamination of drinking-water by arsenic in Bangladesh: A public health emergency. Bull. World Health Organ. 2000, 78, 1093-1103.

10. Niazi, N.K.; Singh, B.; Minasny, B. Mid-infrared spectroscopy and partial least-squares regression to estimate soil arsenic at a highly variable arsenic-contaminated site. Int. J. Environ. Sci. Technol. 2015, 12, 1965-1974. [CrossRef]

11. Du, X.Y.; Tian, M.P.; Wang, X.X.; Zhang, J.; Huang, Q.Y.; Liu, L.P.; Shen, H.Q. Cortex and hippocampus DNA epigenetic response to a long-term arsenic exposure via drinking water. Environ. Pollut. 2018, 234, 590-600. [CrossRef] [PubMed]

12. Gomez, M.L.; Blarasin, M.T.; Martinez, D.E. Arsenic and fluoride in a loess aquifer in the central area of Argentina. Environ. Geol. 2009, 57, 143-155. [CrossRef]

13. Cheng, P.S.; Weng, S.F.; Chiang, C.H.; Lai, F.J. Relationship between arsenic-containing drinking water and skin cancers in the arseniasis endemic areas in Taiwan. Ann. Dermatol. 2016, 43, 181-186. [CrossRef] [PubMed]

14. Tolonen, E.T.; Hu, T.; Ramo, J.; Lassi, U. The removal of sulphate from mine water by precipitation as ettringite and the utilisation of the precipitate as a sorbent for arsenate removal. J. Environ. Manag. 2016, 181, 856-862. [CrossRef] [PubMed]

15. Nguyen, C.M.; Bang, S.; Cho, J.; Kim, K.W. Performance and mechanism of arsenic removal from water by a nanofiltration membrane. Desalination 2009, 245, 82-94. [CrossRef]

16. Safi, S.R.; Gotoh, T.; Iizawa, T.; Nakai, S. Development and regeneration of composite of cationic gel and iron hydroxide for adsorbing arsenic from ground water. Chemosphere 2019, 217, 808-815. [CrossRef] [PubMed]

17. Song, S.; Lopez-Valdivieso, A.; Hernandez-Campos, D.J.; Peng, C.; Monroy-Fernandez, M.G.; Razo-Soto, I. Arsenic removal from high-arsenic water by enhanced coagulation with ferric ions and coarse calcite. Water Res. 2005, 40, 364-372. [CrossRef] [PubMed]

18. Gibbons, M.K.; Gagnon, G.A. Adsorption of arsenic from a Nova Scotia groundwater onto water treatment residual solids. Water Res. 2010, 44, 5740-5749. [CrossRef]

19. Bothe, J.V.; Brown, P.W. Arsenic immobilization by calcium arsenate formation. Environ. Sci. Technol. 1999, 33, 3806-3811. [CrossRef]

20. Donahue, R.; Hendry, M.J. Geochemistry of arsenic in uranium mine mill tailings, Saskatchewan, Canada. Appl. Geochem. 2003, 18, 1733-1738. [CrossRef]

21. Zhang, S.H.; Hu, X.; Lu, Q.; Zhang, J.M. Density functional theory study of arsenic and selenium adsorption on the $\mathrm{CaO}$ (001) surface. Energy Fuels 2011, 25, 2932-2938. [CrossRef]

22. He, L.; Zheng, W.C. Studies of spin-Hamiltonian parameters and defect structures for two tetragonal Ir ${ }^{4+}$ centers in $\mathrm{MgO}$ and $\mathrm{CaO}$ crystals. Radiat. Eff. Defects Solids 2009, 164, 113-117. [CrossRef]

23. Yao, S.N.; Wang, C.L.; Zhang, C.M.; Xiong, H.T.; Miao, W. Influence of the structure of the ordered system $\left(\mathrm{PC}-\mathrm{H}_{2} \mathrm{O}\right)$ on the crystal structure of $\mathrm{CaCO}_{3}$. Acta Phys.-Cnim. Sin. 1997, 13, 270-273.

24. Su, L.B.; Xu, J.; Li, H.J.; Wen, L.; Zhu, Y.Q.; Zhao, Z.W.; Dong, Y.J.; Zhou, G.Q.; Si, J.L. Sites structure and spectroscopic properties of $\mathrm{Yb}$-doped and $\mathrm{Yb}, \mathrm{Na}$-codoped $\mathrm{CaF}_{2}$ laser crystals. Chem. Phys. Lett. 2005, 406, 254-258. [CrossRef]

(C) 2019 by the authors. Licensee MDPI, Basel, Switzerland. This article is an open access article distributed under the terms and conditions of the Creative Commons Attribution (CC BY) license (http://creativecommons.org/licenses/by/4.0/). 